\title{
Faktor Personal dan Sikap Teman mengenai Tindakan Pencegahan Dampak Penularan HIV/AIDS dengan Stigma Mahasiswa Terhadap Orang dengan HIV/AIDS (ODHA)
}

\author{
Rossida Kusuma Dewi ${ }^{1}$, Tanjung Anitasari Indah Kusumaningrum ${ }^{2}$, Mayang Widya \\ Saputri $^{3}$, Dicha Febriyanti ${ }^{4}$, Sonia Pebrianti ${ }^{5}$ \\ 1,2,3,4,5 Program Studi Kesehatan Masyarakat, Fakultas Ilmu Kesehatan, Universitas \\ Muhammadiyah Surakarta \\ Jalan Ahmad Yani Tromol Pos 1 Pabelan Kartasura Surakarta 57102 \\ Email: tanjung.anitasari@ums.ac.id, febriyantidicha22@gmail.com, \\ soniafebrianti46@gmail.com
}

Tanggal Submisi: 21 Juli 2021; Tanggal Penerimaan: 21 September 2021

\begin{abstract}
ABSTRAK
Program pencegahan adanya dampak HIV/AIDS sebagai salah satu bentuk adanya penanggulangan stigma dan diskriminasi terhadap ODHA. Adapun penelitian ini bertujuan untuk menganalisis hubungan faktor personal yang terdiri dari pengetahuan, persepsi dan sikap teman tentang pencegahan dampak HIV/AIDS dengan stigma mahasiswa terhadap ODHA, serta mencari faktor yang paling berpengaruh terhadap stigma mahasiswa pada ODHA. Penelitian ini merupakan observasional analitik dengan pendekatan cross sectional dengan populasi penelitian seluruh mahasiswa angkatan 2016 dan 2017 pada salah universitas di Sukoharjo yang berjumlah 12.457 mahasiswa dengan sampel yang digunakan berjumlah 500 mahasiswa. Teknik pengambilan sampel menggunakan Proportional Random Sampling. Pengumpulan data yang digunakan menggunakan self administered questionnaire dan data dianalisis menggunakan uji Chi-Square pada uji bivariat sementara uji regresi logistic digunakan untuk analisis multivariat. Hasil uji bivariat menunjukkan bahwa ada hubungan antara pengetahuan ( $\mathrm{p}$ value $=0,0001$ ), persepsi $(\mathrm{p}$ value $=0,0001)$, dan sikap teman $(\mathrm{p}$ value $=0,0001)$ dengan stigma mahasiswa terhadap ODHA dengan taraf signifikan $a=0,05$. Uji multivariat didapatkan bahwa sikap teman merupakan faktor yang paling berpengaruh terhadap Stigma Mahasiswa pada ODHA $(\mathrm{OR}=5,627)$. Diperlukan pemberian informasi kepada mahasiswa dan lingkup pertemanannya mengenai HIV/AIDS, serta program penanggulangan HIV untuk mengurangi stigma pada ODHA.
\end{abstract}

Kata kunci : faktor personal, sikap teman, Pencegahan dampak penularan HIV/AIDS, stigma, ODHA

\section{ABSTRACT}

The prevention program of the impact of HIV / AIDS is a form of handling the existence of the stigma and discrimination of PLWHA. This study aims to analyze the relationship of personal factors consisting of knowledge, perceptions and attitudes of friends about prevention the impact of HIV / AIDS with the stigma of student at the PLWHA, as well as looking for the factors that most influence student stigma against people living with HIV/AIDS. This research is an analytic observational study with a cross sectional approach with a research population of all students of the 2016 and 2017 batches classes of the University in Sukoharjo, totaling 12,457 
students with a sample used was 500 students with Proportional Random Sampling. The data collection was using a self administered questionnaire and the data were analyzed using the Chi-Square test in the bivariate test while the logistic regression test was used for multivariate analysis. The results of the bivariate test showed that knowledge ( $p$ value $=0,0001$ ), perception ( $p$ value $=0,0001)$, and the attitudes of friends $(p$ value $=0,0001)$ with stigma of students towards PLWHA with a significant level of $a=0,05$. The multivariate test found that the attitude of friends is the most influential factor on student stigma in PLWHA (OR=5,627). It is necessary to provide information to students and the scope of their friendship about HIV/AIDS, as well as HIV prevention programs to reduce stigma in PLWHA.

Keywords : personal factors, friend attitude, HIV/AIDS, stigma, PLWHA

ISSN 1979-7621 (Print). ISSN 2620-7761 (Online)

DOI $10.23917 / j k . v 14 i 2.15056$

\section{PENDAHULUAN}

Adanya penyakit yang sudah menjadi masalah kesehatan secara global tentu menjadi perhatian untuk diatasi, penyakit tersebut diantaranya adalah penyakit HIV/AIDS. Penyakit HIV/AIDS merupakan salah satu penyakit dengan peningkatan yang cukup tinggi sejak pertama kali ditemukan pada tahun 1987. Menurut data (Kemenkes, 2020) mengenai kejadian kasus HIV di Indonesia bahwa jumlah ODHA yang di laporkan pada tahun 2020 sebanyak 543.100 kasus sedangkan di Provinsi Jawa Tengah khusunya Kabupaten Sukoharjo juga mempunyai kasus HIV/AIDS yang juga mengalami peningkatan dan menurut data Yayasan Sahabat Sehat Mitra Sebaya (YASEMA) sejak bulan Januari hingga September Tahun 2020 secara kumulatif mencapai 650 kasus HIV/AIDS.

Penyakit HIV/ AIDS terjadi karena menurunnya kekebalan tubuh akibat terkena virus yang biasa disebut Human Immunodeficiency Virus. Orang yang menderita penyakit HIV/AIDS tersebut disebut dengan ODHA (Orang dengan HIV/AIDS). ODHA selama hidupnya sering kali mendapatkan pelabelan atau cap akan status HIV-nya. Di Indonesia sekitar 62,8\% laki-laki dan perempuan berusia 15-49 tahun mendiskriminasi ODHA (Situmeang et al., 2017). Berdasarkan ( Riset Kesehatan Dasar, 2018), sebanyak $14,8 \%$ dari 105.659 responden (umur 18-24 tahun) mengucilkan tetangga dengan HIV/AIDS. Stigma di kalangan remaja terjadi karena kurangnya kesadaran akan efek stigma terhadap ODHA (Situmeang et al., 2017). Namun, terdapat jenis respons pencegahan HIV/AIDS di daerah berupa pencegahan dampak. Program tersebut merupakan respons paling minimal penanggulangan stigma HIV/AIDS yang belum berjalan dan terkoordinasi (SRAN, 2010)

Adanya peningkatan kasus HIV, pemerintah berusaha untuk menanggulangi adanya penyakit HIV/AIDS dengan salah satu respon penanggulangan yang ada yaitu pencegahan dampak HIV sebagai upaya untuk mengurangi dampak kesehatan dan sosial ekonomi pada ODHA. Program pencegahan dampak HIV bertujuan untuk menghilangka diskriminasi dalam memberikan layanan dan dalam kehidupan bermasyarakat bagi ODHA. Hal tersebut dilakukan guna meningkatnya kesetaraan kehidupan bermasyarakat bagi ODHA.

Pada orang muda berisiko HIV yaitu usia 15-24 tahun terdapat kegiatan pencegahan dampak HIV/AIDS yang lebih mengutamakan untuk memahami dengan benar dan lengkap mengenai cara penularan HIV dan pencegahannya. Selain itu juga mengajak semua anggota masyarakat untuk tidak mendiskriminasi orang terinfeksi HIV pada semua aspek kehidupan. Dengan hal tersebut maka diharapkan dapat 
terlaksananya pencegahan dampak pada kelompok usia muda.

Mahasiswa merupakan kelompok usia muda yang tergolong remaja akhir. Mahasiswa dianggap agen perubahan yang dapat mensosialisasikan informasi HIV/AIDS, mengurangi stigma dan mempromosikan pencegahan dampak HIV/AIDS. Namun, perlu diingat, untuk mengurangi stigma diperlukan dukungan institusi pendidikan (ICRW, 2013).

Salah satu Universitas yang terdapat di Sukoharjo juga turut berperan mencegah HIV/AIDS. Salah satunya dengan memberikan wadah komunitas peduli HIV/AIDS yang dinaungi Prodi Kesehatan Masyarakat. Komunitas ini bertujuan meningkatkan kepedulian mahasiswa terhadap HIV/AIDS, meningkatkan pengetahuan masyarakat mengenai HIV/AIDS, mencegah penularan penyakit dan menghilangkan stigma serta diskriminasi pada ODHA maupun OHIDA di wilayah tersebut.

Mahasiswa pada salah satu universitas di Sukoharjo tersebut diharapkan juga dapat berperan dalam mengurangi stigma dan diskriminasi pada ODHA namun berdasarkan hasil survei pendahuluan yang dilakukan pada 18-21 Desember 2018 kepada 44 mahasiswa pada salah satu universitas di Sukoharjo didapatkan bahwa terdapat $54,5 \%$ diantaranya memiliki stigma rendah dan $36,3 \%$ sisanya memiliki stigma yang cukup tinggi pada ODHA. Terdapat beberapa faktor yang dapat mempengaruhi pola pandang seseorang terkait ODHA seperti halnya pengetahuan, sikap, maupun persepsi seseorang terkait HIV maupun ODHA.

Berdasarkan penelitian sebelumnya, menyebutkan pengetahuan HIV/AIDS berhubungan signifikan dengan stigma terhadap ODHA. Remaja berpengetahuan rendah berisiko 3 kali menstigma berat ODHA, dibanding remaja berpengetahuan baik tentang HIV/AIDS. Namun pada penelitian (Astuti, 2016), tidak ada hubungan signifikan antara pengetahuan dengan stigma mahasiswa kebidanan terhadap ODHA. Pada penelitian tersebut 109 responden $(50,9 \%)$ berpengetahuan baik, memiliki stigma tinggi pada ODHA. Terdapat 1 responden $(25 \%)$ yang berpengetahuan kurang baik, memiliki stigma tinggi pada ODHA (Maharani, 2017) serta pada penelitian (Situmeang et al., 2017) menyebutkan bahwa prevalensi remaja yang mempunyai stigma terhadap ODHA sebesar $71,63 \%$, prevalensi remaja yang memiliki pengetahuan kurang tentang HIV/AIDS sebesar 49,10\% sehingga lebih berisiko mempunyai stigma terhadap ODHA dibandingkan dengan pengetahuan yang cukup tentang HIV/AIDS. Serta berdasarkan penelitian (Kusumaningrum, 2019) bahwa penggunaan media elektronik yang menjadi pertimbangan petugas kesehatan sebagai sarana peningkatan Informasi mengenai adanya HIV/AIDS informasi yang diberikan dengan cepat mengenai adanya HIV/AIDS juga menjadi salah satu meingkatkan pengetahuan.

Faktor lain yang dapat mempengaruhi stigma yaitu persepsi. Penelitian (Maharani, 2017), dari 79 remaja dengan persepsi positif, hanya $39,2 \%$ yang menstigma rendah ODHA. Sedangkan dari 133 remaja dengan persepsi negatif, 24,8\% menstigma rendah ODHA. Persepsi remaja berhubungan signifikan dengan stigma pada ODHA. Hasil penelitan (Shaluhiyah et al., 2015) mendukung bahwa persepsi berpengaruh pada stigma terhadap ODHA. Responden dengan persepsi negatif berkemungkinan 2 kali lebih besar menstigma ODHA dibanding responden dengan persepsi positif.

Adanya sikap terhadap adanya suatu perilaku merupakan segala bentuk kebiasaan yang digunakan untuk merespon adanya suatu sifat yang positif atau negatif mengenai objek dengan situasi tertentu dengan konsisten sehingga dapat memunculkan suatu interaksi sosial oleh individu tersebut. penelitian Galuh Ajeng (2017) menyatakan bahwa ada kesesuaian antara sikap yang dimiliki dengan adanya tindakan terhadap adanya pencegahan HIV/AIDS sehingga mempunyai kecenderungan untuk bertindak sesuai dengan adanya sikap tersebut.

Selain itu, kelompok teman merupakan faktor yang berhubungan sebagai 
referensi remaja dalam bersikap. Penelitian (Kharimaturrohmah et al., 2013), sikap teman berhubungan dengan stigma ODHA. Sebesar $63,9 \%$ mahasiswa memiliki sikap teman negatif terhadap ODHA sedangkan $31,4 \%$ lainnya mempunyai teman yang bersikap positif terhadap ODHA. Hasil tersebut menunjukkan adanya hubungan signifikan antara sikap teman terhadap stigma pada ODHA.

Mahasiswa sebagai agen perubahan yang diharapkan peranannya dalam program penanggulangan HIV/AIDS maka peneliti tertarik melakukan penelitian mengenai hubungan faktor personal (pengetahuan, persepsi), dan sikap teman tentang pencegahan dampak dengan stigma mahasiswa terhadap ODHA. Tujuan penelitian ini adalah untuk menganalisis hubungan pengetahuan, persepsi dan sikap teman tentang pencegahan dampak HIV/AIDS dengan stigma mahasiswa pada salah satu universitas di Sukoharjo.

\section{METODE PENELITIAN}

Penelitian ini merupakan observasional analitik dengan pendekatan cross-sectional. Penelitian dilaksanakan pada bulan Maret - April 2019 dan tempat penelitian ini meliputi 12 Fakultas yang ada di salah satu Universitas di Sukoharjo dengan populasi dalam penelitian ini adalah seluruh mahasiswa aktif angkatan 2016 dan 2017 yang berjumlah 12.457 mahasiswa dan sampel sejumlah 500 mahasiswa. Teknik pengambilan sampel dalam penelitian ini menggunakan teknik Proportional Random Sampling. Pengambilan data menggunakan self administered questionnaire dengan teknik pengambilan data langsung menyerahkan daftar pertanyaan untuk diisi oleh responden. Analisis data untuk mengetahui hubungan antara variabel bebas yaitu faktor personal yang terdiri dari pengetahuan, persepsi dan sikap teman serta untuk variabel terikat stigma mahasiswa terhadap ODHA dilakukan dengan uji chi square sementara untuk menganalisis faktor yang paling berpengaruh dengan menggunakan uji regresi logistik. Instrument yang digunakan pada penelitian ini telah dilakukan uji validitas dan reabilitasnya dengan hasil variabel pengetahuan $(0,764)$, persepsi $(0,714)$, sikap teman $(0,746)$ dan stigma terhadap ODHA $(0,722)$ sehingga dinyatakan reliabel. Pengkategorian variabel pada penelitian ini yaitu pada variabel faktor personal yang meliputi pengetahuan dengan pengkategorian Baik, Jika skor jawaban $\geq$ 10,35 (mean) dan kurang jika skor jawaban < 10,35 (mean). Pada variabel persepsi tentang pencegahan dampak HIV/AIDS dengan kategori positif, jika skor jawaban $\geq 6,77$ (mean) dan negatif jika skor jawaban $<6,77$ (mean). Pada variabel sikap teman tentang pencegahan dampak HIV/AIDS dengan pengkategorian positif jika skor jawaban $>$ 6,70 (mean) dan negatif jika skor jawaban < 6,70 (mean) serta pada variabel terikat tentang stigma terhadap ODHA dengan pengkategorian tinggi, jika skor jawaban $\geq$ 7,28 (mean) dan rendah jika skor jawaban < 7,28 (mean).

\section{HASIL DAN PEMBAHASAN}

\section{HASIL}

Hasil pengujian karakteristik responden serta hasil uji hubungan antara masing-masing variabel pengetahuan, persepsi, dan sikap teman dengan stigma mahasiswa Universitas di Sukoharjo terhadap ODHA adalah sebagai berikut:

Tabel 1. Distribusi Frekuensi Karakteristik Responden Mahasiswa Universitas di Sukoharjo Surakarta

\begin{tabular}{lccc}
\hline \multicolumn{1}{c}{ Karakteristik } & n & Frekuensi & \% \\
\hline Umur & & & \\
18 & 5 & 12 & 2,4 \\
19 & 0 & 108 & 21,6 \\
20 & 0 & 212 & 42,4 \\
21 & & 136 & 27,2 \\
22 & & 28 & 5,6 \\
23 & & 4 & 0,8 \\
\hline Jenis Kelamin & 5 & & \\
Perempuan & 0 & 265 & 53 \\
Laki-laki & 0 & 235 & 47 \\
\hline Angkatan & 5 & & \\
2016 & 0 & 245 & 49 \\
2017 & 0 & 255 & 51 \\
\hline
\end{tabular}

Tabel 1. Dapat diketahui bahwa responden dalam penelitian ini berjumlah 
sebanyak 500 responden. Gambaran umur responden paling muda adalah 18 tahun, yaitu sebanyak 12 mahasiswa $(2,4 \%)$ dam umur paling tua adalah 23 tahun, yaitu sebanyak 4 mahasiswa $(0,8 \%)$. Dalam penelitian ini, mahasiswa mayoritas berumur 20 tahun yang berjumlah 212 mahasiswa $(42,4 \%)$. Berdasarkan jenis kelamin, jumlah responden mahasiswa yaitu 235 responden (47\%), tidak jauh berbeda dengan jumlah mahasiswi yaitu 265 responden (53\%).

Tabel 2. Distribusi Frekuensi Pengetahuan, Persepsi, Sikap Teman tentang pencegahan dampak HIV/AIDS,

\begin{tabular}{|c|c|c|c|}
\hline Karakteristik & $\mathrm{n}$ & Frekuensi & $\%$ \\
\hline $\begin{array}{l}\text { Pengetahuan } \\
\text { tentang } \\
\text { Pencegahan } \\
\text { dampak } \\
\text { HIV/AIDS } \\
\text { Kurang } \\
\text { Baik }\end{array}$ & 500 & $\begin{array}{l}191 \\
309\end{array}$ & $\begin{array}{l}38,2 \\
61,8\end{array}$ \\
\hline $\begin{array}{l}\text { Persepsi tentang } \\
\text { Pencegahan } \\
\text { dampak } \\
\text { HIV/AIDS } \\
\text { Negatif } \\
\text { Positif }\end{array}$ & 500 & $\begin{array}{l}191 \\
309 \\
\end{array}$ & $\begin{array}{l}38,2 \\
61,8\end{array}$ \\
\hline $\begin{array}{l}\text { Sikap Teman } \\
\text { tentang } \\
\text { Pencegahan } \\
\text { dampak } \\
\text { HIV/AIDS } \\
\text { Negatif } \\
\text { Positif }\end{array}$ & 500 & $\begin{array}{l}194 \\
306\end{array}$ & $\begin{array}{l}38,8 \\
61,2\end{array}$ \\
\hline $\begin{array}{ll}\text { Stigma } & \text { terhadap } \\
\text { ODHA } & \\
\text { Tinggi } & \\
\text { Rendah } & \\
\end{array}$ & 500 & $\begin{array}{l}189 \\
311 \\
\end{array}$ & $\begin{array}{l}37,8 \\
62,2\end{array}$ \\
\hline
\end{tabular}

Berdasarkan Tabel 2, dapat diketahui pula bahwa 309 mahasiswa $(61,8 \%)$ berpengetahuan baik tentang pencegahan dampak HIV/AIDS. Jumlah tersebut lebih banyak dibandingkan mahasiswa yang berpengetahuan kurang tentang pencegahan dampak HIV/AIDS yaitu 191 responden $(38,2 \%)$. Kemudian sebanyak 309 responden $(61,8 \%)$ mahasiswa memiliki persepsi positif tentang pencegahan dampak HIV/AIDS. Hal ini juga lebih banyak dibandingkan mahasiswa dengan persepsi negatif tentang pencegahan dampak HIV/AIDS yaitu 191 responden $(38,2 \%)$.

Selanjutnya mahasiswa dengan sikap teman yang positif tentang pencegahan dampak HIV/AIDS ada 306 responden $(61,2 \%)$. Sedangkan 194 responden $(38,8 \%)$ mahasiswa lainnya memiliki sikap teman yang negatif tentang pencegahan dampak HIV/AIDS. Stigma yang tinggi terhadap ODHA ditemukan pada 189 responden $(37,8 \%)$, sedangkan 311 responden $(62,2 \%)$ sisanya memiliki stigma yang rendah terhadap ODHA.

Hasil pengujian hipotesis hubungan antara masing-masing variabel pengetahuan, persepsi, dan sikap teman dengan stigma mahasiswa terhadap ODHA ditampilkan pada tabel 3.

Tabel 3. Hubungan Pengetahuan, Persepsi dan Sikap Teman tentang Pencegahan dampak HIV/AIDS dengan Stigma Mahasiswa terhadap ODHA

\begin{tabular}{|c|c|c|c|c|c|c|c|c|}
\hline \multirow{3}{*}{ Variabel } & \multicolumn{6}{|c|}{ Stigma Mahasiswa terhadap ODHA } & \multirow{3}{*}{$P$ value } & \multirow{3}{*}{ Contingency Coefficient } \\
\hline & \multicolumn{2}{|c|}{ Tinggi } & \multicolumn{2}{|c|}{ Rendah } & \multicolumn{2}{|c|}{ Total } & & \\
\hline & n & $\%$ & n & $\%$ & n & $\%$ & & \\
\hline $\begin{array}{lr}\text { Pengetahuan } & \text { tentang } \\
\text { Pencegahan dampak HIV/AIDS }\end{array}$ & & & & & & & & \\
\hline $\begin{array}{l}\text { Kurang } \\
\text { Baik }\end{array}$ & $\begin{array}{l}120 \\
69\end{array}$ & $\begin{array}{l}62,8 \\
22,3\end{array}$ & $\begin{array}{l}71 \\
240\end{array}$ & $\begin{array}{l}37,2 \\
77,7\end{array}$ & $\begin{array}{l}191 \\
309\end{array}$ & $\begin{array}{l}100 \\
100\end{array}$ & 0,0001 & 0,376 \\
\hline $\begin{array}{l}\text { Persepsi tentang Pencegahan } \\
\text { dampak HIV/AIDS }\end{array}$ & & & & & & & & \\
\hline $\begin{array}{l}\text { Negatif } \\
\text { Positif }\end{array}$ & $\begin{array}{l}121 \\
68\end{array}$ & $\begin{array}{l}63,4 \\
22,0\end{array}$ & $\begin{array}{l}70 \\
241\end{array}$ & $\begin{array}{l}36,6 \\
78,0\end{array}$ & $\begin{array}{l}191 \\
309\end{array}$ & $\begin{array}{l}100 \\
100\end{array}$ & 0,0001 & 0,383 \\
\hline $\begin{array}{lcr}\text { Sikap } & \text { Teman } & \text { tentang } \\
\text { Pencegahan dampak HIV/AIDS }\end{array}$ & & & & & & & & \\
\hline $\begin{array}{l}\text { Negatif } \\
\text { Positif }\end{array}$ & $\begin{array}{l}132 \\
57\end{array}$ & $\begin{array}{l}68,0 \\
18,6\end{array}$ & $\begin{array}{l}62 \\
249\end{array}$ & $\begin{array}{l}32,0 \\
81,4\end{array}$ & $\begin{array}{l}194 \\
306\end{array}$ & $\begin{array}{l}100 \\
100\end{array}$ & 0,0001 & 0,445 \\
\hline
\end{tabular}

Tabel 3 menunjukkan bahwa tentang pencegahan dampak HIV/AIDS mahasiswa yang berpengetahuan baik cenderung memiliki stigma yang rendah 
terhadap ODHA, yaitu sebanyak 240 orang $(77,7 \%)$ daripada persentase mahasiswa berpengetahuan kurang sebanyak 71 orang (37,2\%). Selanjutnya hasil uji Chi Square diperoleh hasil $p$ value 0,0001 lebih kecil dari nilai tingkat kemaknaan $\alpha<0,05$ sehingga $\mathrm{H}_{0}$ ditolak. Dapat disimpulkan, ada hubungan pengetahuan tentang pencegahan dampak HIV/AIDS dengan stigma Mahasiswa terhadap ODHA. Selain itu nilai Contingency Coefficient sebesar 0,376, sehingga dapat diketahui bahwa pengetahuan tentang pencegahan dampak HIV/AIDS memiliki keeratan hubungan yang tergolong rendah dengan stigma terhadap ODHA.

Hubungan antara persepsi tentang pencegahan dampak HIV/AIDS dengan stigma mahasiswa terhadap ODHA yaitu pada mahasiswa yang memiliki persepsi positif tentang pencegahan dampak HIV/AIDS cenderung memiliki stigma yang rendah terhadap ODHA, yaitu sebanyak 241 orang $(78 \%)$ daripada persentase mahasiswa yang memiliki persepsi negative yaitu sebanyak 70 orang $(36,6 \%)$. Selanjutnya hasil uji Chi Square diperoleh hasil $p$ value 0,0001 lebih kecil dari nilai tingkat kemaknaan $\alpha<0,05$ sehingga $\mathrm{H}_{0}$ ditolak. Dapat disimpulkan, ada hubungan persepsi tentang pencegahan dampak HIV/AIDS dengan stigma Mahasiswa terhadap ODHA. Selain itu nilai Contingency Coefficient sebesar 0,383, sehingga dapat diketahui bahwa persepsi tentang pencegahan dampak HIV/AIDS memiliki keeratan hubungan yang tergolong rendah ODHA.

Hubungan antara sikap teman tentang pencegahan dampak HIV/AIDS dengan stigma mahasiswa terhadap ODHA yaitu pada mahasiswa yang memiliki sikap teman positif tentang pencegahan dampak HIV/AIDS cenderung memiliki stigma yang rendah terhadap ODHA, yaitu sebanyak 249 orang $(81,4 \%)$ daripada persentase mahasiswa yang memiliki persepsi negative yaitu sebanyak 62 orang (32\%). Selanjutnya hasil uji Chi Square diperoleh hasil $p$ value 0,0001 lebih kecil dari nilai tingkat kemaknaan $\alpha<0,05$ sehingga $\mathrm{H}_{0}$ ditolak.
Dapat disimpulkan, ada hubungan persepsi tentang pencegahan dampak HIV/AIDS dengan stigma mahasiswa terhadap ODHA. Selain itu nilai Contingency Coefficient sebesar 0,445, sehingga dapat diketahui bahwa sikap teman tentang pencegahan dampak HIV/AIDS memiliki keeratan hubungan yang tergolong sedang dengan stigma terhadap ODHA.

\section{Uji Kesesuaian Model}

Tabel 4. Hosmer and Lemeshow Test

\begin{tabular}{llll}
\hline Step & Chi-square & df & Sig. \\
\hline 1 &, 896 & 5 &, 970
\end{tabular}

ho : Model sesuai

h1 : Model tidak sesuai

Ditolak jika $p<a$. Berdasarkan Tabel 5. diatas dapat dilihat bahwa nilai Karena nilai $p=0,970$ lebih besar dari pada taraf signifikansi $(p>0,05)$ maka dapat disimpulkan bahwa model sesuai. Dapat disimpulkan model ini layak digunakan untuk memprediksi besarnya peluang Stigma Mahasiswa Terhadap ODHA sebagai upaya Tindakan Pencegahan Dampak Penularan HIV/AIDS.

Tabel 5 Omnibus Tests of Model Coefficients

\begin{tabular}{lllll}
\hline & & Chi-square & df & Sig. \\
\hline \multirow{3}{*}{ Step 1 } & Step & 189,461 & 3 &, 0001 \\
& Block & 189,461 & 3 &, 0001 \\
& Model & 189,461 & 3 &, 0001 \\
\hline
\end{tabular}

Berdasarkan hasil Tabel 6. diatas dapat dilihat bahwa nilai chi-square yang diperoleh adalah 189,461 dengan derajat kebebasan $=3$, nilai $\mathrm{p}=0,0001$. Karena nilai $\mathrm{p}=0,0001<a=0,05$ maka dapat disimpulkan minimal ada satu variabel independent (pengetahuan, persepsi dan sikap teman) yang berpengaruh signifikan terhadap variabel dependent yaitu stigma mahasiswa terhadap ODHA. 
Tabel 6. Model Summary

\begin{tabular}{lccl}
\hline Step & -2 Log likelihood & $\begin{array}{l}\text { Cox \& Snell R } \\
\text { Square }\end{array}$ & $\begin{array}{l}\text { Nagelkerke } \\
\text { Square }\end{array}$ \\
\hline 1 & \multicolumn{1}{c}{$473,615^{\text {a }}$} &, 315 &, 429 \\
\hline a. & $\begin{array}{l}\text { Estimation terminated at iteration } \\
\text { number } 5 \text { because parameter } \\
\text { estimates changed by less than } \\
\text { b. } 001 .\end{array}$
\end{tabular}

Berdasarkan hasil Tabel 7. pada diatas dapat dilihat bahwa nilai $\mathrm{G}$ adalah 473,615. Kemudian diperoleh nilai Nagelkerke $R$ Square sebesar 0,429 yang berarti bahwa variabel bebas (pengetahuan, persepsi dan sikap teman) mampu menjelaskan $42,9 \%$ keragaman/variasi stigma mahasiswa terhadap ODHA dan sisanya yaitu $57,1 \%$ dijelaskan oleh faktor lain.

\begin{tabular}{llllllllll}
\multicolumn{10}{c}{ Tabel 7. Hasil Analisis Multivariat } \\
\hline & B & S.E. & Wald & df & Sig. & Exp(B) & $95 \%$ & C.I.for \\
& & & & & & & EXP(B) \\
\hline Pengetahuan & 1,240 &, 233 & 28,322 & 1 & 0,0001 & 3,455 & 2,188 & 5,454 \\
Persepsi & 1,102 &, 236 & 21,903 & 1 & 0,0001 & 3,012 & 1,898 & 4,779 \\
Sikap teman & 1,728 &, 233 & 55,209 & 1 & 0,0001 & 5,627 & 3,567 & 8,875 \\
& & & & & & & & & \\
Constant & 1,835 &, 230 & 63,465 & 1 & 0,0001 &, 160 & & \\
& & & & & & & & & \\
\end{tabular}

Pada Tabel 8. diatas, diperoleh nilai signifikan dari ketiga variabel bebas yaitu pengetahuan, persepsi dan sikap teman masing-masing menunjukkan nilai yang sama yakni 0,0001 . Karena nilai signifikan sebesar 0,0001 < $a=0,05$ maka Ho ditolak yang artinya variabel pengetahuan, persepsi dan sikap teman berpengaruh signifikan terhadap variabel dependent yaitu stigma mahasiswa terhadap ODHA dalam tindakan pencegahan dampak penularan HIV/AIDS dimana masing-masing memiliki OR variabel pengetahuan berpeluang sebesar 3,455 kali lebih besar mempengaruhi stigma mahasiswa terhadap ODHA, OR variabel persepsi berpeluang sebesar 3,012 kali lebih besar mempengaruhi stigma mahasiswa terhadap ODHA serta OR Sikap teman merupakan variabel yang paling berpengaruh terhadap stigma mahasiswa pada ODHA (OR=5,627) dengan arti mahasiswa yang memiliki sikap teman yang positif terhadap upaya pencegahan dampak HIV/AIDS akan berpeluang 5,627 lebih besar memiliki stigma yang rendah terhadap ODHA dibandingkan dengan yang tidak memiliki paparan terhadap variabel bebas tersebut.

\section{PEMBAHASAN}

Melalui Analisis multivariat, variabel sikap teman tentang program pencegahan dampak HIV/AIDS merupakan variabel yang paling berpengaruh terhadap stigma pada mahasiswa terhadap ODHA dengan odds ratio sebesar 5,627 dimana hal ini berarti mahasiswa yang mempunyai sikap teman positif mengenai upaya pencegahan dampak Penularan HIV/AIDS akan berpeluang 5,627 lebih besar memiliki stigma yang baik terhadap ODHA dibandingkan dengan yang tidak memiliki paparan terhadap variabel tersebut. Hal ini sejalan dengan penelitian terdahulu dimana dalam penelitian yang dilakukan oleh (Kharimaturrohmah et al., 2013) menyatakan bahwa ada hubungan yang signifikan antara sikap teman terhadap ODHA dengan stigma ODHA. Mahasiswa yang menstigma ODHA mayoritas mempunyai teman bersikap negatif terhadap ODHA, dimana dalam perkembangannya sangat dipengaruhi oleh lingkungannya khususnya teman sebaya. Hasil penelitian ini juga didukung oleh penelitian (Farotimi et al., 2015) yang menyatakan bahwa responden dengan sikap positif berkaitan dengan strategi mengurangi stigma dan diskriminasi HIV/AIDS cenderung memiliki stigma yang rendah terhadap ODHA. Yang mana 96 orang $(64 \%)$ dari 150 responden memiliki sikap positif dan stigma maupun diskriminasi yang rendah.

Berdasarkan pertanyaan dalam kuesioner mengenai sikap teman tentang pencegahan dampak HIV/AIDS, sebesar $85,8 \%$ mahasiswa menjawab setuju stigma pada ODHA dapat dikurangi dengan pencegahan dampak melalui sosialisasi HIV/AIDS. Disamping itu, sebesar 85,4\% mahasiswa juga setuju bahwa pencegahan dampak HIV/AIDS itu perlu karena temannya peduli. Akan tetapi masih terdapat sebesar $42,6 \%$ kesalahpahaman sikap teman mahasiswa yang beranggapan bahwa 
temannya setuju jika pencegahan dampak HIV/AIDS tidak dapat mengurangi stigma pada ODHA. Hal tersebut belum tentu karena dengan paham dan tahu pencegahan dampak HIV/AIDS diharapkan mahasiswa justru dapat mengurangi stigma pada ODHA.

Oleh sebab itu, perlu dilakukan suatu upaya sebagai rencana aksi untuk mengurangi stigma terhadap ODHA. Menurut (Nugroho \& Kusumaningrum, 2018) Stigma masyarakat dapat perlahan memudar dengan dilakukannya sosialisasi tentang HIV/AIDS dan VCT dengan penjelasan sudut pandang mengenai keadilan sosial yaitu pemanfaatan layanan kesehatan bagi populasi berisiko serta perlunya peer educator yang rajin untuk memotivasi kelompoknya untuk melakukan tes dan memberikan informasi yang lebih lengkap terhadap dampak penularan HIV untuk mencegah penularan serta mengurangi stigma dan diskriminasi oleh petugas kesehatan dalam layanan kesehatan. Hal ini merupakan upaya pemerintah dalam menyebarluaskan informasi terkait HIV/AIDS \& VCT kepada masyarakat yang dilakukan melalui pihak-pihak yang bergerak dalam penanggulangan HIV/AIDS yaitu LSM, KPA maupun Dinas Kesehatan. Selain itu, Dalam lingkup universitas dapat pula dikembangkan suatu wadah yang memberikan informasi terkait kesehatan reproduksi dan juga HIV/AIDS yang Salah satunya yaitu melalui pembentukan PIK-M (Pusat Informasi Konseling Mahasiswa) yang didalamnya juga membahas informasi berkaitan dengan HIV/AIDS.

Variabel lainnya yang berpengaruh terhadap program pencegahan dampak HIV/AIDS terhadap stigma pada mahasiswa yaitu adalah Varibel Pengetahuan dengan odds ratio sebesar 3,455 yang berarti mahasiswa yang mempunyai pengetahuan yang baik mengenai upaya pencegahan dampak penularan HIV/AIDS akan berpeluang 3,445 lebih besar memiliki stigma yang baik terhadap ODHA. Berdasarkan pertanyaan dalam kuesioner variabel pengetahuan tentang pencegahan dampak HIV/AIDS, sebesar 95\% mahasiswa menjawab benar jika salah satu gejala HIV/AIDS adalah menurunnya tingkat kekebalan tubuh. Namun masih tinggi kesalahpahaman pengetahuan mahasiswa yaitu sebesar $89,6 \%$ menganggap program pencegahan dampak berfokus pada sektor kesehatan. Hal tersebut salah karena pencegahan dampak HIV/AIDS juga melibatkan sektor kesehatan, pendidikan, sosial, hukum, penanggulangan narkotika, ketenagakerjaan, kepolisian, pemberdayaan perempuan, dan keluarga berencana. Pencegahan dampak merupakan upaya untuk mengurangi dampak tidak hanya pada kesehatan tetapi juga sosial ekonomi hingga mencegah stigma dan diskriminasi pada ODHA.

Sementara itu hampir setengah dari total responden $(49,4 \%)$ salah menjawab bahwa HIV/AIDS dapat ditularkan melalui berciuman bibir. Berdasarkan Kusumaningrum (2018), cara penularan HIV/AIDS yaitu melalui hubungan seks, transfusi darah, narkoba suntik dengan jarum suntik yang dipakai secara bergantian, Air Susu Ibu (ASI), dari Ibu hamil yang positif HIV ke anaknya serta dari kecelakaan medis. Penelitian lain yang dilakukan oleh ( Ningsih, 2018) juga menyatakan pengetahuan responden tentang HIV/AIDS menurunkan stigma mahasiswa terhadap ODHA. Hasil penelitian ini juga didukung oleh penelitian yang dilakukan (Maharani, 2017) yang menyatakan remaja berpengetahuan rendah berisiko 3 kali lebih besar memberikan stigma pada ODHA, dibanding remaja berpengetahuan baik tentang HIV/AIDS. Pengetahuan tentang HIV/AIDS khususnya tentang mekanisme penularan, over estimasi terhadap risiko kontak langsung, dan sikap negatif terhadap ODHA sangat berhubungan dengan berkembangnya stigma pada ODHA.

Adanya ketakutan yang berlebih pada ODHA ini dapat meningkatkan stigma. Oleh sebeb itu, diperlukannya peran institusi pendidikan khususnya dosen agar melibatkan mahasiswanya dalam sosialisasi pencegahan dampak HIV/AIDS bertujuan untuk menambah informasi dan pengetahuan 
mahasiswa tentang bahaya HIV/AIDS dan pengurangan stigma pada ODHA yang dapat mulai dilakukan saat awal adanya PK-PMB mahasiswa baru sehingga sejak dini mahasiswa dapat mengerti pentingnya pencegahan terhadap dampak penularan hingga pengurangan stigma pada ODHA.

Variabel lainnya yang berpengaruh dalam penelitian terhadap program pencegahan dampak HIV/AIDS terhadap stigma pada mahasiswa yaitu adalah Varibel Persepsi dengan odds ratio sebesar 3,012 yang memiliki arti dimana mahasiswa yang mempunyai persepsi positif tentang pencegahan dampak HIV/AIDS akan berpeluang 3,012 lebih besar memiliki stigma yang baik terhadap ODHA. Hal ini sejalan dengan penelitian lain yang dilakukan oleh (Maharani, 2017) dimana menyebutkan bahwa persepsi berhubungan sebab akibat dengan stigma berat terhadap ODHA. Hal tersebut juga didukung oleh penelitian (Shaluhiyah et al., 2015) yang menyatakan bahwa responden dengan persepsi negatif terhadap ODHA memiliki kemungkinan 2 kali lebih besar memberikan stigma terhadap ODHA dibandingkan dengan responden yang memiliki persepsi positif. Persepsi masyarakat terhadap ODHA berpengaruh terhadap sikap dan perilaku memberikan stigma. Demikian juga persepsi terhadap penderita AIDS akan sangat memengaruhi cara orang tersebut bersikap dan berperilaku terhadap ODHA. Selain itu, (Paryati et al., 2013) juga mengungkapkan persepsi negatif terhadap ODHA sangat mempengaruhi stigma atau pandangan buruk terhadap ODHA. Persepsi terhadap ODHA ini berkaitan dengan nilai-nilai seperti rasa malu, sikap menyalahkan dan menghakimi yang berhubungan dengan penyakit AIDS tersebut Persepsi yang salah terhadap HIV/AIDS menjadi penyebab remaja takut untuk berinteraksi langsung dengan ODHA, sehingga remaja memiliki stigma terhadap ODHA (Hutapea, 2011)

Dalam kuesioner, pertanyaan persepsi tentang pencegahan dampak HIV/AIDS, sebesar 93\% mahasiswa setuju bahwa dengan mendukung aktivitas sosial pada ODHA merupakan contoh pencegahan dampak HIV/AIDS. Selain itu sebesar 91,8\% mahasiswa setuju jika pencegahan dampak HIV/AIDS membantu mahasiswa untuk melindungi diri dari infeksi HIV/AIDS. Namun hampir setengah dari total responden $(46,2 \%)$ masih tinggi kesalahpahaman persepsinya karena menganggap dengan adanya ODHA pada suatu lingkungan, menunjukkan terdapat penyimpangan sosial di tempat tersebut. Tidak semua ODHA merupakan orang yang berperilaku menyimpang. Bisa jadi kondisi tersebut disebabkan bukan karena kesalahannya sendiri. Karena HIV bisa tertular melalui beberapa alasan. Sementara itu sebesar $41,6 \%$ mahasiswa setuju bahwa dengan menghindari kontak langsung dengan ODHA merupakan upaya pencegahan dampak HIV/AIDS. Hal tersebut tidak dibenarkan karena dengan menghindari ODHA hanya akan membuat penderitanya semakin menjauh dari masyarakat. Selain itu karena hilangnya kepercayaan diri untuk masih dianggap sebagai bagian dari suatu lingkungan.

Dengan demikian, sebagai bentuk upaya untuk mengurangi persepsi negative terhadap ODHA, perlu dilaksanakan kegiatan yang positif oleh institusi pendidikan untuk mengubah persepsi tersebut serta perlunya peran serta untuk melibatkan mahasiswanya sebagai penyuluh sebaya sebagai sumber informasi yang benar tentang HIV/AIDS, Baik itu cara penularan maupun cara mencegah agar mahasiswa tidak tertular HIV/AIDS.

\section{KESIMPULAN}

Mahasiswa yang dilibatkan dalam penelitian adalah mahasiswa berumur 18-25 tahun. Responden paling banyak berumur 20 tahun $(42,4 \%)$ dan paling sedikit berumur 23 tahun $(0,8 \%)$. Mahasiswa perempuan sebanyak $53 \%$ dan laki-laki $47 \%$. Tahun angkatan 2017 sebanyak 51\% dan 2016 sebanyak 49\%. Ada hubungan antara pengetahuan tentang pencegahan dampak HIV/AIDS dengan stigma mahasiswa terhadap ODHA ( $p$ value $=0,0001)$ dan 
R K Dewi, T A I Kusumaningrum, M W Saputri, D Febriyanti \& S Pebrianti / Jurnal Kesehatan 14 (2) 2021, 184-194

Contingency Coefficient yang tergolong rendah sebesar 0,376. Mahasiswa dengan pengetahuan tentang pencegahan dampak HIV/AIDS yang kurang cenderung memiliki stigma yang tinggi terhadap ODHA. Ada hubungan antara persepsi tentang pencegahan dampak HIV/AIDS dengan stigma Mahasiswa terhadap ODHA ( $p$ value $=0,0001$ ) dan Contingency Coefficient yang tergolong rendah sebesar 0,383. Ada pula hubungan antara sikap teman tentang pencegahan dampak HIV/AIDS dengan stigma Mahasiswa Universitas di Sukoharjo terhadap ODHA ( $p$ value $=0,0001)$ dan Contingency Coefficient yang tergolong sedang sebesar 0,445. Sikap teman merupakan variabel yang paling berpengaruh terhadap adanya stigma pada mahasiswa tentang pencegahan dampak HIV/AIDS dengan $\mathrm{OR}=5,627$ kemudian diikuti oleh Variabel Pengetahuan dengan $\mathrm{OR}=3,455$ dan yang terakhir yaitu variabel persepsi dengan $\mathrm{OR}=3,012$. Dengan demikian, sebagai upaya untuk menghindari dan melindungi diri dari risiko infeksi HIV serta mengurangi stigma terhadap ODHA hendaknya diperlukan adanya pemberian informasi, penyuluhan dan akses media informasi tentang HIV/AIDS

\section{DAFTAR PUSTAKA}

Astuti, D. (2016). ISSN 2407-9189 The 4 th Univesity Research Coloquium 2016 Faktor-Faktor Yang Mempengaruhi Stigma Mahasiswa ISSN 2407-9189 The 4 th Univesity Research Coloquium 2016. 279-286.

Farotimi, A., Nwozichi, C., \& Ojediran, T. (2015). Knowledge, attitude, and practice of HIV/AIDS-related stigma and discrimination reduction among nursing students in southwest Nigeria. Iranian Journal of Nursing and Midwifery Research, 20(6), | Vol.20 | Issue 6.

Hutapea, Ronald. (2011). AIDS \& PMS dan Pemerkosaan. Jakarta : Rineka Cipta.

Kemenkes RI. (2017). Laporan Perkembangan AIDS dan PIMS di Indonesia Jakarta: Ditjen P2P Kemenkes RI.

Kharimaturrohmah, I., Shaluhiyah, Z., Promosi, M., Universitas, K., \& Semarang, D. (2013). P. Pengaruh Sikap Teman Dan Orangtua Terhadap Stigma ODHA Oleh Mahasiswa Keperawatan STIKes Kota Yogyakarta, 8(2), 131-140. Jurnal Promosi Kesehatan Indonesia. Vol.8 / No.2.

Kusumaningrum,T.A.I, dan Sholekhah, Banun. 2019. Akes Informasi Mengenai HIV/AIDS pada Mahasiswa Universitas Muhammadiyah Surakarta.Seminar Nasional Kesehatan Masyarakat UMS.

Komisi Penanggulanggan AIDS Kota Surakarta. (2018). Laporan Data Kasus HIV/AIDS Kota Surakarta 2018. Komisi Penanggulangan AIDS.

Maharani, F. (2017). Faktor -Faktor Yang Berhubungan Dengan Stigma Terhadap Orang Dengan Hiv Dan Aids (Odha). Jurnal Endurance, 2(2), 158.

Ningsih S, Bahtiar H, dan Khaeri S. (2018). Hubungan Pengetahuan Tentang HIV/AIDS Dengan Stigma Orang Dengan HIV/AIDS (ODHA) Di Kalangan 
R K Dewi, T A I Kusumaningrum, M W Saputri, D Febriyanti \& S Pebrianti / Jurnal Kesehatan 14 (2) 2021, 184-194

Mahasiswa STIKES Yarsi Mataram. Journal Ilmiah STIKES Yarsi Mataram, Vol. 1, No.1.

Nugroho, C., \& Kusumaningrum, T. A. I. (2018). Isyarat Bertindak sebagai Faktor Pendorong Lelaki Seks Lelaki dalam Melakukan Voluntary Counseling and Testing. Jurnal Promosi Kesehatan Indonesia, 13(2), 101.

Paryati, T., Raksanagara, A. S., Afriandi, I., \& Kunci, K. (2013). Faktor-faktor yang Mempengaruhi Stigma dan Diskriminasi kepada ODHA(Orang dengan HIV/AIDS) oleh petugas kesehatan : kajian literatur. Pustaka Unpad, 38, 1-11.

Pangestika G, Saraswati L D dan Mateus S. (2017). Gambaran Faktor Personal Yang Melatarbelakangi Tindakan Pencegahan Penularan HIV/AIDS Pada Warga Binaan Dengan HIV Positif (Studi Kualitatif di Lembaga Permasyarakatan Wanita Klas IIA Kota Semarang). Jurnal Kesehatan Masyarakat. Vol 1 (1).

Shaluhiyah, Z., Musthofa, S. B., \& Widjanarko, B. (2015). Stigma Masyarakat terhadap Orang dengan HIV/AIDS. Kesmas: National Public Health Journal, 9(4), 333.

Situmeang, B., Syarif, S., \& Mahkota, R. (2017). Hubungan Pengetahuan HIV/AIDS dengan Stigma terhadap Orang dengan HIV/AIDS di Kalangan Remaja 15-19 Tahun di Indonesia (Analisis Data SDKI Tahun 2012). Jurnal Epidemiologi Kesehatan Indonesia, 1(2), 35-43.

Sosodoro, O., Emilia, O., \& Wahyuni, B. (2009). Hubungan Pengetahuan Tentang Hiv/Aids Dengan Stigma Orang Dengan Hiv/Aids Di Kalangan Pelajar Sma. Berita Kedokteran Masyarakat, 25(4), 210-217.

SRAN. (2010). Strategi dan Rencana Aksi Nasional Penanggulangan HIV dan AIDS Tahun 2010-2014. Jakarta : KPAN.

St Xavier's college, ICRW, UNDP, STRIVE. (2013). Integrating a youthbased stigma and discrimination reduction curriculum in higher education CASE STUDY St Xavier's College. 